\title{
Leder: Temanummer om
} forebygging av fordommer og gruppefiendtlige holdninger i skolen

\author{
Trine Anker og Claudia Lenz \\ $M F$ vitenskapelig høyskole for teologi, religion og samfunn, Norge
}

Våren 2020 startet en serie med protester mot rasisme og politivold i USA etter at George Floyd ble anholdt av politiet og kvalt til døde av en politimann under pågripelsen. Protestene ble en del av Black Lives Matter-bevegelsen og spredde seg rundt i verden. I Oslo deltok mange tusen i demonstrasjonene som ble holdt foran Stortinget og utenfor den amerikanske ambassaden. Korona-restriksjoner og smittevern satte liten begrensning for engasjementet. Dette ledet også til at mange med minoritetsbakgrunn sto frem i mediene og fortalte om opplevelser med å bli forskjellsbehandlet, ekskludert og/eller trakassert. En del fortalte også om negative opplevelser fra skoletiden.

Slike fortellinger er ikke ukjent i utdanningsforskning, og flere senere studier har pekt på at undervurdering og andregjøring av enkeltelever og grupper av elever er et problem i dagens skole (Antirasistisk senter, 2017; Chinga-Ramirez, 2015, 2021; Svendsen, 2014). Debattene har ført til at begreper som fra før var ukjente for mange, nå har blitt koblet til konkrete erfaringer. Vi har fătt et offentlig ordskifte om blant annet hverdagsrasisme, rasialisering og mikroaggresjon.

I kjølvannet av Black Lives Matter-demonstrasjonene har vi fått mange og viktige diskusjoner om rasisme, om hvordan rasisme skal defineres og hva fenomenet innebærer. Det er lett å få øye på og ta avstand fra synlig, ideologisk motivert rasisme, men vanskeligere å få grep om mer subtile former for nedsettende eller ekskluderende adferd og underliggende institusjonelle strukturer og praksiser. Dette er et viktig utgangspunkt for en refleksjon om hvordan rasismen spiller seg ut i skolen.

Det samme gjelder for andre former for fordommer og negativ forskjellsbehandling, som kan være basert på kjønn og kjønnsidentitet, legning eller funksjonsevne. Fra tidligere forskning (Røthing, 2010; Røthing \& Bang Svendsen, 2011) vet vi at

^Korrespondanse: Trine Anker, e-post: trine.anker@mf.no

(C) 2021 T. Anker \& C. Lenz. This is an Open Access article distributed under the terms of the Creative Commons Attribution 4.0 International License (https://creativecommons.org/licenses/by-nc/4.0/), allowing third parties to copy and redistribute the material in any medium or format and to remix, transform, and build upon the material for any purpose, even commercially, provided the original work is properly cited and states its license.

Citation: T. Anker $\mathcal{E}$ C. Lenz. "Leder: Temanummer om forebygging av fordommer og gruppefiendtlige holdninger $i$ skolen» Nordisk tidsskrift for pedagogikk og kritikk, Special issue: Forebygging av fordommer og gruppefientlighet. Vol. 7, 2021, pp. 99-103. http://dx.doi.org/10.23865/ntpk.v7.3256 99 
skolen både reproduserer og utfordrer forestillinger om normalitet og avvik. Flere av artiklene i dette temanummer viser at det kan være snakk om sammensatte fenomener, der for eksempel kjønn, religion og etnisitet kan krysse og forsterke hverandre. Lærere og lærerutdannere trenger en grunnleggende profesjonskompetanse for å manøvrere i disse fenomenene. Det er samtidig behov for arenaer for profesjonell samhandling og for å utvikle, utfordre og videreutvikle egen praksis.

Bidragene i dette temanummer et inngår $i$ en faglig diskusjon om hvordan skolen og lærerutdanningen kan fylle sitt mandat om å forebygge og motarbeide fordommer og diskriminering. I det nye reviderte læreplanverket for grunnskole og videregående opplæring (LK20), gradvis innført fra og med høsten 2020, gis det spesifikke føringer for at skolen skal «fremme demokratiske verdier og holdninger som motvekt mot fordommer og diskriminering» (Kunnskapsdepartementet, 2017, s. 8). Dette er en utdyping og konkretisering av formålsparagrafens vektlegging av den enkelte elevens menneskeverd og retten til et trygt skolemiljø ( $(9 \mathrm{a})$. Dokumentene for skolens arbeid gienspeiles i lærerutdanningens planer. I rammeplan for lektorutdanning 8-13 finner vi en kobling mellom arbeidet for trygt læringsmiljø, jf. $\ 9$ a og forebygging av rasisme og diskriminering. Dette er videre utdypet i Nasjonale retningslinjer (6.3), der det spesifiseres at lærerstudenter etter endt utdanning skal ha kompetanse til å oppdage, håndtere og forebygge rasisme og diskriminering.

Det er en lang tradisjon i de nordiske land for at skolene skal ha en sentral rolle $i$ å fremme demokratiske verdier. En slik eksplisitt kobling av idealet om demokratiske verdier med forebygging av fordommer og diskriminering er imidlertid forholdsvis nytt i læreplansammenheng. Det er behov for å satse på dette arbeidet både i skolen og i lærerutdanningen. En kartlegging utført av Universitet i Stavanger viser at temaene fordommer, gruppefiendtlighet og rasisme generelt er svakt representert $i$ pensumlitteraturen på lærerutdanningene, og at lærerne på disse institusjonene synes det er vanskelig å undervise om dette (Thomassen et al., 2017). Dermed er det behov for en systematisk utvikling av læreres kompetanse. Arbeidet forutsetter en styrket bevissthet om sammenhenger mellom utenforskap, ekskludering og opplevd avmakt på den ene siden og utvikling av fordommer og gruppefiendtlige holdninger på den andre. Dette innebærer å utvikle selvinnsikt og kritisk forståelse av egne tolkningsrammer og blindsoner, samt forståelse for hvordan etablerte praksiser, institusjonelle og samfunnsmessige rammer medvirker i å skape og opprettholde andregjøring og utenforskap.

Dembra (Demokratisk beredskap mot rasisme, antisemittisme og udemokratiske holdninger) har siden 2012 støttet skolenes arbeid med forebygging av gruppefiendtlighet og utenforskap. Dette ble videreutviklet til også å omfatte lærerutdanninger fra og med høsten 2017 (Dembra-LU). Per i dag har lærerutdannere fra 10 institusjoner samarbeidet om å utvikle undervisningsformer og -opplegg, men også om å skape lærende profesjonsfelleskap innad og på tvers av institusjonene. Initiativet til dette temanummeret springer ut av dette faglige samarbeidet, og vi håper det vil bidra til flere faglige diskusjoner og utviklingsprosesser langt ut over Dembra-prosjektet. 
Temanummeret inneholder ulike perspektiver på forebyggende arbeid og har en bred tilnærming til feltet.

De fire første artiklene har et kritisk blikk på språklige konstruksjoner og forståelser av rasisme og rasialisering. Artiklene er basert på empirisk forskning fra utdanningsfeltet, men med vekt på ulike grupper: elever, lærer og lærerutdannere. I sin i artikkel "Mot utvidede forståelser av rasialisering og rasisme i skolen» argumenterer Kristin Gregers Eriksen for at fenomenene rasialisering og rasisme ikke bør forstås som rene kognitive fenomener, men som nedfelt i affektive strukturer knyttet til nasjonal identitet. Hun har foretatt observasjoner av undervisning i samfunnsfag på mellomtrinnet. Hennes argument er at det må jobbes frem en dypere forståelse av rasialisering og rasisme for at skolen skal kunne jobbe målrettet med sitt demokrati- og anti-rasistiske arbeid.

Ingvild Bjørkeng Haugens artikkel «Emitted and omitted discourses on diversity - time to admit privilege, race and power?» viser hvordan mangfold blir forstått i utdanningsfeltet og hvilken betydning dette kan ha for sosialt rettferdige praksiser. Haugen analyserer læreres refleksjoner over mangfold og konkluderer med at de i stor grad utelukker kategorier som knyttes til etnisitet og rase.

Hanne Riese og Yael Harlap diskuterer språklige konstruksjoner av det norske i lærerutdanningen i sin artikkel «Utdanning, rasialisering og tilhørighetens grensen». Basert på funn fra analyser av dialoger mellom studenter og forelesere i fire bacheloremner ved to norske universiteter viser de hvordan det skapes grenser for tilhørighet som bidrar til rasialisering av deler av befolkningens. Med utgangspunkt i funnene diskuterer artikkelen utdanningssystemets rolle i å utfordre diskursivt konstruerte maktstrukturer.

I artikkelen «Norske elevers konseptualisering av rasismebegrepet» studerer Fredrik Hagen elevenes perspektiver på rasisme. Basert på analysen av fokusgruppeintervjuer med elever på ungdomstrinnet konkluderer han med at elevene plasser er rasisme som et historisk og individuelt fenomen, og at de derfor ikke kobler samtidige hendelser til begrepet rasisme, selv når disse er konsekvenser av rasistisk ideologi.

Som nevnt tidligere sikter normkritiske perspektiver i utdanningen på å belyse og endre underliggende forestillinger og tolkningsmønstre som plasserer individer og grupper utenfor det «normale» og anerkjente. Temanummeret inneholder to artikler som omhandler normkritiske perspektiver i utdanning. Begge disse bruker normkritiske perspektiver, men har også et kritisk blikk på hvordan normkritikk kan bidra til å utvikle nye blindsoner.

I sin artikkel «Normkritisk pedagogik - framväxten och utvecklingen av ett nytt begrepp $i$ den svenska utbildningskontexten» rekonstruerer Lotta Björkman og Janne Bromseth normkritiske perspektiver gjennomslag i den svenske skolen. Normkritisk utdanning forstås av forfatterne som utdanning som er kritisk til privilegier og andregjøring og utdanning som endrer studenter og samfunnet (jf. Kumashiro, 2002). Forfatterne tar imidlertid også opp kritiske perspektiver på normkritisk pedagogikk, spesielt risikoen for at en ukritisk anvendelse av normkritiske perspektiver kan bidra til å skape nye normer og essensialiserende subjektposisjoner. 
Eva Bolander og Anna Bredström fokuserer på såkalt svenske verdier i sin artikkel «Det kritiska hoppet:Vikten av att synliggöra rasism $i$ undervisning om värdegrundsfrågor på språkintroduktion». Forfatterne har gjort en aksjonsrettet etnografisk studie sammen med lærere og elever på det svenske gymnasets språkintroduksjon. Her finner de at kjønn (genus) og seksualitet brukes som etniske markører på svenskhet og ikke-svenskhet. De viser til potensialet ved å bruke et antirasistisk, kritisk perspektiv på elevenes egne erfaringer og derved bryte med ideen om en forestilt normativ svenskhet.

De fire siste artiklene tar for seg tolkningsrammer og praksiser der fordommer, andregjøringsmekanismer og diskriminering er, eller kan være, i spill i skolen og lærerutdanningen.

Joke Dewilde og Thor-André Skrefsrud spør om skolers bruk av flerkulturelle samlinger fremmer eller hindrer fordommer og negative holdninger mot grupper i sin artikkel «Revisiting studies of multicultural school events from the perspective of strategic essentialism».

Forfatterne argumenterer mot tidligere forskning som hevder at slike hendelser bidrar til å reprodusere eksotifiserende kulturelle stereotypier. De bruker begrepet strategisk essensialisme for å vise at slike arrangementer kan gi minoritetsforeldre en mulighet til å være aktivt handlende subjekter på en majoritetsarena.

I artikkelen "Nedsettende - og innafor? Lareres erfaringer med elevers bruk av stereotypier og fordomsuttrykk $i$ klasserommet» undersøker Tonje Myrebøe lærernes usikkerhet og ubehag i møte med fordomsuttrykk i ungdomsskole og videregående skole. På den ene siden innebærer slike ytringer mulige krenkelser av sårbare elever. På den andre siden har ytringene ulike sosiale funksjoner, og det er flytende grenser mellom hva som oppfattes som spøk og hva som oppfattes som rasistiske og diskriminerende praksiser. Myrebøe beskriver hvordan lærerne beveger seg mellom ulike posisjoner i situasjonene de opplever som utfordrende.

I artikkelen "Laererens makt og avmakt $i$ et flerkulturelt klasserom. En analyse av lererstudenters profesjonsetiske forståelse» utforsker Trine Anker og Claudia Lenz egen undervisning for lektorstudenter, der målet er å utvikle studenters profesjonsetiske forståelse relatert til diskriminering og rasisme i skolen. Med utgangspunkt i studenttekster finner forfatterne at studentene beskriver et bredt spekter av årsaksfaktorer til konflikter i et klasserom, blant dem institusjonelle og strukturelle aspekter. Handlingsstrategiene som identifiseres er derimot langt mer individualisert. Med utgangspunkt i funnene drøftes det hvordan kritisk og normkritisk pedagogikk kan bidra til bredere profesjonsetisk handlingsorientering.

Kari Spernes' artikkel «Lererstudenters bevisstgjøring av sammenhengen mellom begrepsbruk og oppfattet annerledeshet» er også basert på forskning på egen praksis i lærerutdanningen. Hun undersøker hvorvidt en oppgave om begrepsbruk kan bevisstgjøre grunnskolelærerstudenter om holdninger til generalisering og stereotypisering. Gjennom en analyse av lærerstudentenes refleksjoner om begrepene 'foreldre' og 'innvandrerforeldre' viser Spernes at begrepene er med på å bestemme om studentene 
vektlegger foreldrerolle eller kultur, og at dette påvirker hvordan de ser på samarbeidet med foreldrene.

Vi setter stor pris på de bidragene vi har fått inn, og all jobben som har vært gjort gjennom prosessen med å klargjøre for publisering. Artiklene gir tilskudd til en akademisk og nyansert debatt om hvordan vi skal håndtere rasisme, gruppefiendtlige holdninger og andregjøring i skole og lærutdanning. Vi håper og tror dette vil bidra med ny innsikt og være til hjelp for dem som jobber med og forsker på disse utfordrende og sammensatte temaene.

Oslo, juni 2021

\section{Gjesteredaktørene}

Trine Anker / MF vitenskapelig høyskole for teologi, religion og samfunn

Claudia Lenz / MF vitenskapelig høyskole for teologi, religion og samfunn

\section{Referanser}

Antirasistisk senter. (2017). "Vi vil ikke leke med deg fordi du er brun» (Forskningsrapport). https://antirasistisk. no/publikasjoner/leke-brun-undersokelse-opplevd-rasisme-blant-ungdom/

Chinga-Ramirez, C. (2015). Skolen ser ikke hele meg! En postkolonial og narrativ studie av sosial ulikhet $i$ den videregående skolen gjennom minoritetselevers erfaringer av å vare annerledes [Doktorgradsavhandling, Norges teknisk-naturvitenskapelige universitet]. NTNU Open. http://hdl.handle.net/11250/2364846

Chinga-Ramirez, C. (2021). Hvordan skapes utenforskap i skolen? Ikke-vestlig minoritetsungdom forteller sine historier. I I. K. Sørenssen, T. Abebe \& M. Ursin, Barndomsstudier i norsk kontekst: Tverrfaglige tilncerminger (s. 235-258). Gyldendal Akademisk.

Kunnskapsdepartementet. (2017). Verdier og prinsipper for grunnopplaringen - overordnet del av laereplanverket. Regjeringen. https:/www.regjeringen.no/no/dokumenter/verdier-og-prinsipper-for-grunnopplaringen/id 2570003/

Røthing, Å. (2008). Homotolerance and heteronormativity in Norwegian classrooms. Gender and Education, 20(3), 253-266. https://doi.org/10.1080/09540250802000405

Røthing, Å. \& Svendsen, S. H. B. (2011). Sexuality in Norwegian textbooks: Constructing and controlling ethnic borders? Ethnic and Racial Studies, 34(11), 1953-1973. https://doi.org/10.1080/01419870.2011. 560275

Svendsen, S. H. B. (2014) Learning racism in the absence of 'race.' European fournal of Women's Studies, 21(1), 9-24. https://doi.org/10.1177/1350506813507717

Thomassen, W. E., Malmo, K.-A. \& Munthe, E. (2017). Lceremiddelbruk og behov i grunnskolelcererutdanning 5-10. Rapport til Utdanningsdirektoratet, Universitetet i Agder. 